\title{
TSNA Levels in the Mainstream Smoke of Simplified Blend Prototypes*
}

\author{
by \\ Sandrine d'Andres, Roxane Boudoux, Jean-Marc Renaud, and Jacques Zuber \\ Philip Morris International, Research and Development, clo Philip Morris Product SA, Quai Jeanrenaud 56, CH-2003 \\ Neuchâtel, Switzerland
}

\section{SUMMARY}

Different approaches have been reported in the literature to reduce the tobacco-specific nitrosamine (TSNA) levels in mainstream smoke (MSS). The reduction of TSNA in the raw tobacco is an approach that has received much attention in recent years. Different elements determine the level of TSNA in MSS: During combustion, part of the TSNA in the cigarette filler can transfer into smoke while another portion can undergo thermal degradation. Moreover, it is possible that TSNA can be pyrosynthesized and that concomitant synergetic effects between the blend components can also occur. Depending on their extent, the formation and degradation of nitrosamines during the combustion process might have an important impact on TSNA level in the smoke of blended cigarettes and might lead to MSS TSNA deliveries which would not parallel that of the blend components.

A study was therefore undertaken to assess the feasibility of predicting the TSNA deliveries of blended products on the basis of the TSNA deliveries of the individual blend components. A highly simplified blend-model was chosen, including laminar Virginia, burley and Oriental tobaccos in fixed proportions. A set of one-, two- and three-component prototypes was prepared with various combinations of highand low-TSNA Virginia and burley tobacco. The pre-formed TSNA levels of the different blend components and the MSS delivery of the prototypes were determined.

The TSNA deliveries of the blended prototypes were found to be in good agreement with the predictions based on both the MSS TSNA delivery and the pre-formed TSNA content of the individual blend components.

This study showed that predicting MSS TSNA levels in the smoke of blended cigarettes could probably be achieved with adequate accuracy from the levels measured in the smoke of the laminar blend components. Strong indications were obtained that such predictions could be made from the preformed TSNA content of the raw tobacco.

With respect to the reduction of TSNA in MSS, the reported results provided evidence that procuring tobaccos with very low levels of pre-formed TSNA would be an effective strategy to reduce the content of TSNA in MSS. [Beitr. Tabakforsch. Int. 20 (2003) 331-340]

\section{ZUSAMMENFASSUNG}

In der Literatur finden sich verschiedene Ansätze, um den Gehalt an tabakspezifischen Nitrosaminen (TSNA) im Hauptstromrauch (HSR) von Zigaretten zu reduzieren. Ein Vorgehen, dem in den letzten Jahren viel Aufmerksamkeit geschenkt wurde, ist die Verringerung der TSNA im Rohtabak. Die Höhe der TSNA Konzentration im HSR wird von verschiedenen Faktoren bestimmt: Während der Verbrennung kann ein Teil der TSNA aus dem Zigarettentabak in den Rauch übergehen, während ein anderer Teil thermisch zersetzt werden kann. Darüber hinaus ist es möglich, dass TSNA während der Pyrolyse synthetisiert werden und damit einhergehende synergistische Effekte zwischen den Komponenten der Tabakmischung auftreten. Abhängig von ihrem Ausmaß, können die Bildung und die Zersetzung der Nitrosamine während des Verbrennungsprozesses für die TSNA Konzentrationen im Rauch von Blendzigaretten von großer Bedeutung sein und zu TSNA Freisetzungen im HSR führen, die in ihrer Höhe nicht den Freisetzungen der Komponenten der Tabakmischung entsprechen.

Aus diesem Grund wurde eine Untersuchung durchgeführt um zu prüfen, ob die Höhe der TSNA Freisetzung von Blendtabakprodukten auf der Basis der TSNA Freisetzung der einzelnen Blendkomponenten vorhergesagt werden kann. Ein sehr vereinfachtes Blendmodell wurde gewählt, das aus Virginia, Burley und Orient Laminartabak in festgesetzten Proportionen bestand. Eine Anzahl an Prototypen bestehend aus einer, zwei oder drei Komponenten, die aus den unterschiedlichsten Kombinationen von Virginia und Burley Tabak mit hohen und niedrigen TSNA Konzentrationen bestanden, wurde hergestellt. Die vorhandenen TSNA Konzentrationen der verschiedenen Blendkomponenten und die TSNA Freisetzung im HSR der Prototypen wurden bestimmt. Es wurde festgestellt, dass die TSNA Freisetzung der Blendprototypen mit den Vorhersagen, die sowohl auf der TSNA Freisetzung im HSR als auch auf der vorgegebenen TSNA Konzentration der einzelnen Blendkomponenten basierte, gut übereinstimmte.

Diese Untersuchung hat gezeigt, dass die TSNA Konzentrationen im HSR von Blendzigaretten wahrscheinlich mit ausreichender Genauigkeit auf der Basis der im Rauch der 
einzelnen (laminaren) Blendkomponenten gemessenen Konzentrationen vorhergesagt werden können. Es gab auch vermehrte Hinweise darauf, dass solche Vorhersagen auf der Basis der vorhandenen TSNA Konzentrationen im Rohtabak gemacht werden können.

Hinsichtlich der Reduzierung der TSNA im HSR weisen die Ergebnisse der Untersuchung darauf hin, dass die Verwendung von Tabaken mit einer sehr niedrigen TSNA Konzentration zu einer Verringerung des TSNA Gehalts im HSR führen könnte. [Beitr. Tabakforsch. Int. 20 (2003) 331-340]

\section{RESUME}

Diverses approches visant à réduire la teneur en nitrosamines spécifiques du tabac (NAST) dans le courant de fumée principal ont été rapportées dans la littérature. La réduction de la teneur en NAST du tabac brut est une approche qui a fait l'objet d'une attention particulière au cours des dernières années. La teneur en NAST dans la fumée du courant principal dépend de plusieurs facteurs : Au cours de la combustion, une partie des NAST présentes dans le tabac de la cigarette peut être transférée dans la fumée, tandis qu'une autre partie peut se dégrader sous l'effet de la chaleur. Il est également possible que des NAST se forment par pyrosynthèse ; dans ce cas, des effets synergiques entre les différents composants du mélange pourraient apparaître. Selon leur importance, la formation et la dégradation des nitrosamines au cours de la combustion pourraient avoir un impact important sur la teneur en NAST de la fumée de cigarettes fabriquées à partir de mélanges de tabac. Ceci pourrait conduire pour la fumée des mélanges à des rendements en NAST qui ne reflèteraient pas ceux des composants individuels du mélange.

La présente étude a été menée afin de déterminer s'il est possible de calculer le rendement en NAST de cigarettes fabriquées à partir de mélanges de tabac sur la base des rendements en NAST des composants individuels de ces mélanges. Un mélange très simple comprenant des tabacs écôtés de type Virginie, Burley et Oriental dans des proportions définies a été choisi comme modèle. Une gamme de prototypes constitués de un, deux ou trois composants et incluant diverses combinaisons de tabacs Virginie et Burley riches ou pauvres en NAST a été confectionnée. Les teneurs en NAST ont été déterminées dans les tabacs utilisés pour confectionner les mélanges ainsi dans que dans le courant principal de fumée des prototypes.

Les rendements en NAST des prototypes constitués à partir de mélanges de tabacs se sont avérés être en bon accord avec les prédictions établies aussi bien sur la base des teneurs en NAST dans la fumée des composants individuels, que sur la base des nivaux de NAST préformées de ces mêmes composants.

Cette étude montre que la teneur en NAST dans la fumée de cigarettes fabriquées à partir de mélanges de tabacs peut vraisemblablement être prédite avec une précision acceptable à partir des niveaux mesurés dans la fumée des composants des limbaires des mélanges. De solides indications ont été obtenues montrant que de telles prédictions peuvent également être faites sur la base des teneurs en NAST préformées des composants des mélanges.

En ce qui concerne la réduction du rendement en NAST dans la fumée du courant principal, les résultats obtenus indiquent que l'utilisation de tabacs ayant une très faible teneur en NAST préformées constitue une stratégie efficace pour réduire le contenu en NAST dans la fumée du courant principal. [Beitr. Tabakforsch. Int. 20 (2003) 331-340]

\section{INTRODUCTION}

A range of different approaches has been evaluated in the literature to reduce the level of nitrosamines present in mainstream smoke (MSS). While filtration with cellulose acetate has proven very effective for the volatile nitrosamines, such is not the case for the tobacco-specific nitrosamines (TSNA). A traditional line of research has attempted to reduce the TSNA level in smoke through reduction of the TSNA content of the raw tobacco. This avenue has received much attention in recent years as significant progress has been achieved especially with flue cured tobacco $(1,2)$.

In order to take full advantage of lower TSNA contents in raw tobacco, it is of prime importance to have a clear understanding of the mechanisms that lead to the presence of the TSNA in smoke. In particular, one needs to assess whether the direct transfer of TSNA from tobacco into smoke is primarily responsible for the TSNA levels in MSS or if pyrosynthetic mechanisms are playing a significant role. Should the latter be the case, high TSNA levels could still occur in the smoke of cigarettes made from tobaccos with low levels of pre-formed TSNA. At least three different elements need to be considered: part of the TSNA present in the filler of a combusting cigarette can transfer into smoke while another portion can undergo thermal degradation. Moreover, TSNA could be synthesized from the tobacco alkaloids and a nitrosating species during the smoking process. Unfortunately, as outlined below, the literature provides conflicting views on the respective role of these possible mechanisms. (For a recent review, see BAKER in the tobacco monograph [3]).

Given the high level of efforts by many companies to reduce the TSNA content of cured leaf, it was deemed necessary to gain additional insight in the relationship between the level of TSNA in MSS of blended and of single-grade all-lamina cigarettes and the level of preformed TSNA in the corresponding cigarette cut filler. The present study was therefore undertaken to assess the feasibility of predicting the TSNA deliveries of blended products on the basis of the TSNA deliveries of the individual blend components.

\section{Variation of TSNA levels in commercial tobaccos}

A wide range of TSNA levels (from below the limit of detection up to $30 \mathrm{ppm}$ ) is observed in commercial tobaccos. According to previous studies literature reports, several factors affect the TSNA levels in cured leaves. These include the type of tobacco, geographic origin, crop year, variety, leaf tissue and stalk position. The type of tobacco and the very broad factor designated as geographic origin were shown to have the largest impact on the TSNA levels and are briefly discussed below.

Type of tobacco: It is amply documented in the literature $(4,5,6,7)$ that, in the range of tobaccos used for the manufacturing of American-blended cigarettes, total TSNA are highest in burley tobaccos. They are clearly lower, at least by a factor of two, in flue-cured and are close to or below the detection limit of the analytical methods in Oriental tobacco as illustrated in Figure 1. The distribution of 


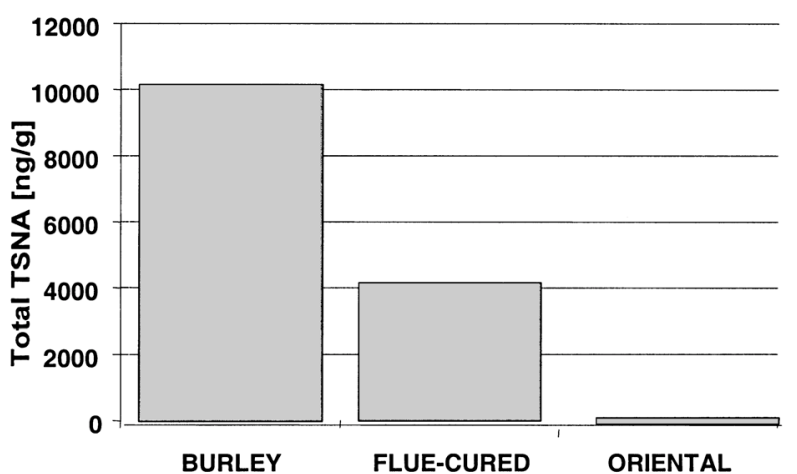

Figure 1. Typical total TSNA levels in US burley, US flue-cured and Greek Oriental tobaccos. Results are expressed in ng TSNA/g tobacco dry weight

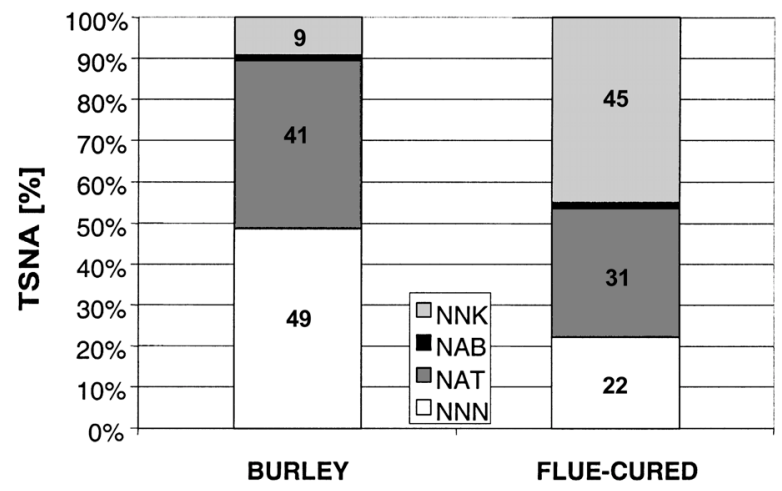

Figure 2. Typical distribution of individual TSNA in US burley and US flue-cured tobacco samples

individual TSNA also differs depending on the type of tobacco (see Figure 2). Both $N$-nitrosonornicotine (NNN) and $\mathrm{N}$-nitrosoanatabine (NAT) are predominant in burley tobacco, accounting, in approximately equal proportion, for $90 \%$ of the total TSNA. NNK (4- $(N$-methyl- $N$-nitrosamino)-1-(3-pyridyl)-1-butanone) is predominant in fluecured tobacco, accounting for approximately $50 \%$ of the total TSNA levels.

Geographic origin: In an earlier study conducted by our research group, TSNA levels were determined in tobacco strips from different producing countries all over the world (Figure 3). Striking differences were seen among the different origins. Despite seasonal and sample-to-sample variability as illustrated in Figure 4, rather consistent differences in TSNA levels among tobaccos from different origins were observed throughout the data set.

The geographic origin is not a well-defined factor; it represents an aggregate of pedo-climatic conditions, agroomic practices and curing conditions. The data measured for flue-cured tobacco were in good qualitative agreement with previous findings (2) on the role of nitrogen oxides on TSNA formation during the flue-curing process: Growing areas where heat exchangers were in general use or where conventional flue-curing was performed in barns typically equipped with flues, produced tobaccos with significantly lower TSNA levels than areas which generally rely on direct-fire heating systems. For burley, none of the climatic, agronomic or curing parameters monitored during two con-

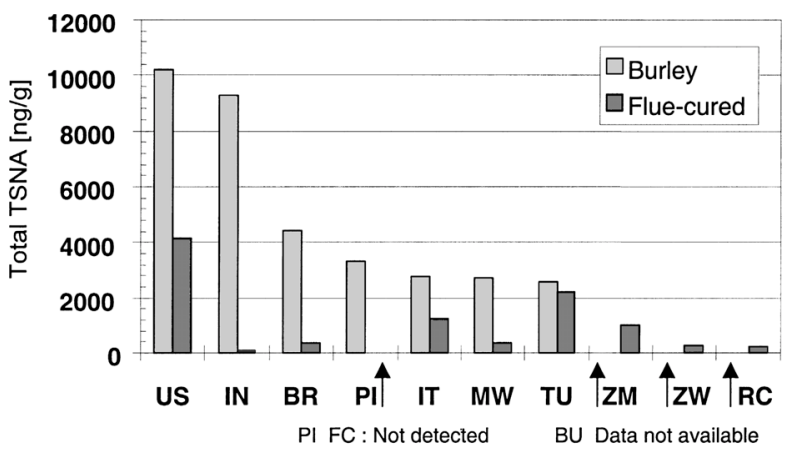

Figure 3. Average total TSNA (ppb) in burley and flue-cured tobaccos from different origins. Average values include different crop years between 1990 and 1998 (BR: Brazil, IN: India, IT: Italy, MW: Malawi, PI: Philippines, RC: Republic of China, US: United States of America, TU: Turkey, ZM: Zambia, ZW: Zimbabwe). Results are expressed in ng TSNA/g tobacco dry weight.

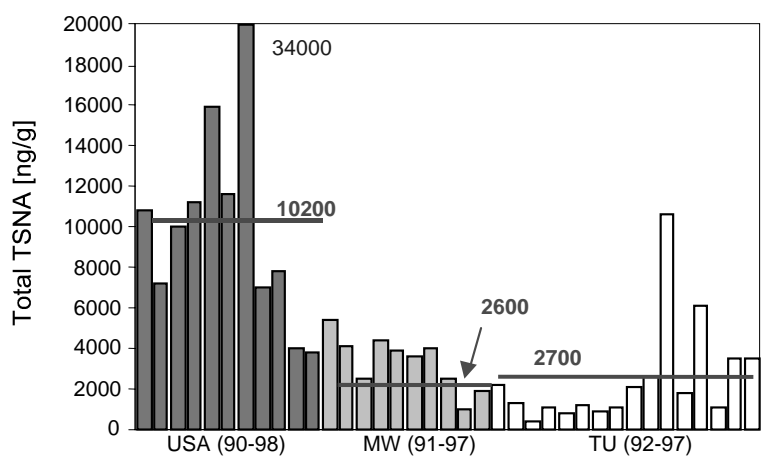

Figure 4. Total TSNA levels in burley tobacco samples from the USA, Malawi (MW) and Turkey (TU) from different crop years between 1990 and 1998. Horizontal bars indicate mean TSNA levels expressed in ng TSNA/g tobacco dry weight.

secutive crop years (1997-1998) could be identified as having a dominant impact on the TSNA levels. However, rainfall and atmospheric moisture at the end of the yellowing stage of the burley tobacco were shown to favor bacterial development and thus to lead to higher TSNA levels in burley tobacco (8).

\section{TSNA levels in MSS}

TSNA can occur in MSS through two mechanisms, namely transfer from tobacco and/or formation during the combustion process from an alkaloid precursor and a nitrosating agent (pyrosynthesis). There are in the literature conflicting conclusions regarding the respective contribution of both mechanisms to total TSNA in MSS. Based on the use of cigarettes fortified with ${ }^{14} \mathrm{C}-\mathrm{NNN}$, HoFFMANN et al. (9) concluded that $46 \%$ of MSS NNN originated from the tobacco, the other $54 \%$ being formed during the combustion process. Experiments reported by ADAMS et al. (10) using [methyl${ }^{14}$ C]nicotine indicated that $26-37 \%$ of the NNK in the smoke derived directly from the tobacco, whereas the rest was pyrosynthesized. On the other hand, FISCHER et al. (11) have concluded from studies based on the fortification of 
Table 1. Experimental design: one and two component experimental prototypes ( $s=$ single component, $d=$ dual component)

\begin{tabular}{|c|c|c|c|c|c|c|c|c|}
\hline \multirow[b]{2}{*}{ Component $^{\mathrm{a}}$} & \multirow[b]{2}{*}{ Origin } & \multicolumn{3}{|c|}{$\mathrm{BU}$} & \multicolumn{3}{|c|}{ FC } & \multirow{2}{*}{$\frac{\mathrm{OP}}{\mathrm{GP}}$} \\
\hline & & US & MW & TU & US & BR & IN & \\
\hline \multirow[t]{3}{*}{$\mathrm{BU}$} & US & $\mathrm{s}$ & $d$ & $d$ & $d$ & $d$ & $d$ & $d$ \\
\hline & MW & & $\mathrm{s}$ & - & $d$ & $d$ & $d$ & $d$ \\
\hline & TU & & & s & $d$ & $d$ & $d$ & $d$ \\
\hline \multirow[t]{3}{*}{ FC } & US & & & & $\mathrm{s}$ & $d$ & $d$ & $d$ \\
\hline & BR & & & & & $\mathrm{s}$ & - & $d$ \\
\hline & IN & & & & & & $\mathrm{s}$ & $d$ \\
\hline OR & GR & & & & & & & $\mathrm{s}$ \\
\hline
\end{tabular}

aStandard-TSNA tobaccos: burley (BU) and flue-cured (FC) tobacco from the USA, Oriental (OR) tobacco from Greece (GR) low-TSNA tobaccos: burley tobacco from Malawi (MW) and Turkey (TU), flue-cured tobacco from Brazil (BR) and India (IN).

cigarettes with nicotine and nitrate that pyrosynthesis of NNN does not occur and that this mechanism is very unlikely for NNK, at least for cigarettes with lower nitrate levels (the authors indicated a possible contribution of pyrosynthesis for nitrate-rich, dark cigarette types). The study by FISCHER et al. also included an experiment using cigarettes fortified with [pyrrolidine-2- ${ }^{14} \mathrm{C}$ ] nicotine, which led the authors to further conclude that NNN and NNK were not synthesized from nicotine during smoking.

The type of tobacco has an impact on the TSNA delivery to MSS. Several authors suggested that the most important factor for the delivery of nitrosamines in smoke is the nitrate content of the tobacco. HOFFMANN et al. (12) observed that the smoke of cigarettes made entirely of burley tobacco is richer in TSNA than that of cigarettes made of flue-cured or blended tobaccos. They concluded that high levels of nitrate in tobacco, nitrogen oxides in the smoke and elevated $\mathrm{pH}$ appear to favor the formation of nonvolatile $N$-nitrosamines in the smoke. This was in agreement with the observation made by FISCHER et al. (11) that nitrate-rich dark tobacco cigarettes showed much higher mainstream-to-tobacco ratios for NNK than all other cigarettes. Although these studies suggest a higher mainstream-to-tobacco ratio for burley than for flue-cured tobacco, none of them concluded whether this was explained by different pyrosynthesis propensities or different transfer rates.

No information was available from the literature on the relationship between the MSS TSNA delivery of blended products with the pre-formed TSNA levels of the individual components of the blend. This relationship is expected to be complex because of the following two factors: The uncertainty about the effective contribution of pyrosynthesis to MSS TSNA and the possible impact of reactions between chemical substrates from different components of the blend. According to present knowledge from the literature and from information collected within Philip Morris, two opposite effects might result from cross reactions between the blend components: a transmission of the higher pyrosynthesis propensity of one component (e.g., from high-nitrate burley) to other components of the blend (e.g., Virginia) or a reduction of the pyrosynthetic formation of TSNA due to the presence of a nitrosation inhibitor
Table 2. Experimental design: three-component experimental prototypes

\begin{tabular}{l|c|c|c|c|c|c|c|c|c|c}
\hline Com- & \multirow{2}{*}{$\begin{array}{c}\text { Level } \\
\text { ponent }\end{array}$} & \multicolumn{10}{c}{ [\%] } & T1 ${ }^{\mathrm{a}}$ & T2 & T3 & T4 & T5 & T6 & T7 & T8 & T9 \\
\hline BU & 30 & US & MW & TU & US & US & MW & TU & MW & TU \\
FC & 50 & US & US & US & BR & IN & BR & BR & IN & IN \\
OR & 20 & GR & GR & GR & GR & GR & GR & GR & GR & GR
\end{tabular}

aT1: Standard three-component experimental prototype.

in the Oriental tobacco component. The presence of such an inhibitor was hypothesized based on the observation that Oriental tobaccos are extremely low in TSNA although precursors, i.e. alkaloids and nitrate are present in measurable amounts.

\section{Purpose and strategies}

The purpose of the present study was to determine the feasibility of predicting the MSS TSNA deliveries of blended all-lamina products based on the TSNA levels in either the MSS or the tobacco of the corresponding tobacco filler components.

The approach adopted was to manufacture a set of experimental cigarette prototypes using extremely simplified blends of two or three laminar components and to compare the measured MSS TSNA deliveries of those prototypes with the levels that could be predicted, firstly, on the basis of the MSS TSNA deliveries of the corresponding singlecomponent experimental cigarettes and, secondly, based on the levels of pre-formed TSNA in the individual components of the tobacco filler.

Flue-cured, burley and Oriental tobacco strips were blended in the following proportions: $50 \%$ flue-cured : $30 \%$ burley : $20 \%$ Oriental. For the two-component prototypes, the blend components were combined in equal proportions. For the flue-cured and burley components, tobaccos from different origins were selected so that the experiment included samples with a range of TSNA level (see Figures 3 and 4). By substituting the burley and the flue-cured components, a set of experimental prototypes containing various levels of TSNA was prepared. No substitution was performed for the Oriental tobaccos, as the TSNA levels were consistently extremely low. The design of the experiment is summarized in Tables 1 and 2.

\section{MATERIAL AND METHODS}

\section{Test tobaccos}

A set of 7 tobaccos including burley, flue-cured and Oriental was used. The burley and the flue-cured samples were each selected from three growing countries. The USA were chosen as the source for standard-TSNA burley and flue-cured tobaccos. The corresponding low-TSNA samples were taken from Indian and Brazilian flue-cured lots and from Turkish and Malawi burley lots. For each origin, between 3 and 11 lots were sampled (in Philip Morris 
Table 3. Cigarette prototype specifications

\begin{tabular}{ll}
\hline Parameter & Specification \\
\hline Filter & \\
Filter material & Cellulose acetate \\
Filter length & $20 \mathrm{~mm}$ \\
Filter rod RTD & $422 \mathrm{~mm} \mathrm{WG}$ \\
Cigarette & \\
Cigarette length & $84 \mathrm{~mm}$ \\
Cigarette diameter & $8 \mathrm{~mm}$ \\
Cigarette paper name & Mauduit 137-1 hfe \\
Cigarette ventilation & $0 \%$ \\
Tobacco rod firmness & $2.8 \mathrm{~mm}$ \\
Tobacco weight & \\
\hline
\end{tabular}

${ }^{\text {a RTD }}=$ Resistance to draw

${ }^{\mathrm{b}}$ The cigarettes were made to constant tobacco rod firmness.

Products warehouses), tested for pre-formed TSNA and the samples closest to the middle of the measured range for each combination of type and origin were selected for the experiment. Only one origin, Greece, was selected for the Oriental tobacco as comparable and very low TSNA levels were observed in the various samples from Greece and Turkey.

\section{Preparation of experimental cigarette prototypes:}

King-size filter experimental cigarette prototypes were prepared according to the specifications provided in Table 3. The tobacco weight was adjusted for each prototype in order to produce cigarettes with identical firmness. For each blend, 500 weight-selected cigarettes were kept as test samples. In total, 35 different prototypes were prepared, including 7 single-, 19 two- and 9 three-component blends.

\section{Reagents}

Dichloromethane (Lichrosolv for liquid chromatography) and acetone (analytical grade) were obtained from Merck (Dietikon, Switzerland) and from Fluka (Buchs, Switzerland) respectively. TSNA standards, $N$-nitrosoanabasine (NAB), NAT, NNK and NNN, (purity >98\%) were purchased from NCI Chemical Carcinogen Reference Standard Repository c/o Midwest Research Institute (Kansas City, MI, USA). $N$-nitrosodihexylamine (NDHEXA) (purity 96-98\%) was obtained form Toronto Research Chemicals Inc. (North York, Canada). Alumina (Aluminum oxide 90), Activity II according to Brockmann, was obtained from ICN Biomedicals (Eschwege, Germany). The buffer solution ( $\mathrm{pH}$ 4.5) used in the trapping train and for the extraction of the Cambridge filters consisted of a solution of $60 \mathrm{mM}$ citric acid, $90 \mathrm{mM}$ of sodium phosphate, dibasic $\left(\mathrm{Na}_{2} \mathrm{HPO}_{4}\right)$, and $20 \mathrm{mM}$ L-ascorbic acid in deionized water. All chemicals used for the preparation of the buffer solution were of analytical grade and were purchased from Fluka (Buchs, Switzerland).

\section{Instrumentation}

The machine smoking of cigarettes was performed using a Borgwaldt 20-port rotary smoking machine, model RM20, from H. Borgwaldt GmbH (Hamburg Germany). GC analyses were performed using a HP5890 gas chromatograph equipped with an auto-sampler 7673A, both from Agilent Technologies (Waldbronn, Germany). The gas chromatograph was interfaced to a thermal energy analyzer (TEA), Model 543, Thermedics (Chelmsford, MA, USA). The detector signal was processed using a PE Nelson, Turbochrom 6.1.2 data acquisition system from Perkin Elmer Instruments (Rotkreuz, Switzerland).

\section{Analysis of pre-formed TSNA}

A 2.5-g tobacco strip sample was extracted overnight with $100 \mathrm{~mL}$ of dichloromethane and $1 \mathrm{~mL}$ of water on an orbital shaker. After filtration over a filter paper and concentration to approximately $3 \mathrm{~mL}$ using a rotaryevaporator, the extract was purified by chromatography over alumina using a mixture of dichloromethane/acetone (9:1) as eluent. After addition of the $1.5 \mu \mathrm{g}$ of internal standard NDHEXA solution in dichloromethane, the column eluate was concentrated to $1.5 \mathrm{~mL}$ and analyzed by GC-TEA on a $30 \mathrm{~m} \times 0.53 \mathrm{~mm}$ i.d. fused-silica column coated with $1.5 \mu \mathrm{m}$ of methyl, $5 \%$ phenyl silicone (DB-5, $\mathrm{J} \& \mathrm{~W})$. The oven temperature was programmed from 100 to $200{ }^{\circ} \mathrm{C}$ at $8{ }^{\circ} \mathrm{C} / \mathrm{min}$ and maintained at this temperature for $5 \mathrm{~min}$. The injection was carried out in the splitless mode and the injection port temperature was $200{ }^{\circ} \mathrm{C}$. Two replicate analyses per sample were performed.

\section{Analysis of TSNA in MSS}

Ten cigarettes were conditioned and smoked according to conditions specified in the relevant International Standards (ISO) $(13,14)$, using a twenty-port rotary smoking machine. The mainstream smoke of the test cigarettes was collected through a trapping train which consisted of two $250-\mathrm{mL}$ impingers containing each $100 \mathrm{~mL}$ of $\mathrm{pH} 4.5$ buffer solution with $3.5 \mathrm{~g} / \mathrm{L}$ of ascorbic acid as the nitrosation inhibitor. The impingers were backed up by a 9-mm Cambridge filter. After each puff, a rinsing puff of nitrogen was drawn through the sample collection train. After completion of the smoking, the TSNA were extracted from the Cambridge filter pad with $100 \mathrm{~mL}$ of $\mathrm{pH}-4.5$ buffer. The extract was pooled with the content of the impingers and the nitrosamines were partitioned into dichloromethane ( 3 times 100 $\mathrm{mL}$ ). The organic layer was concentrated to $3 \mathrm{~mL}$ on a rotary evaporator and purified by chromatography over an alumina column (Activity II, according to Brockmann) using dichloromethane in order to discard interfering compounds, followed by a 9:1 mixture of dichloromethane and acetone as eluent. After addition of $0.4 \mu \mathrm{g}$ of internal standard (NDHEXA), solution in dichloromethane, the column eluate was concentrated to $3 \mathrm{~mL}$ and analyzed by GC-TEA on a 30 $\mathrm{m} \times 0.53 \mathrm{~mm}$ i.d. fused-silica column coated with $1.5 \mu \mathrm{m}$ of methyl, 5\% phenyl silicone (DB-5, J\&W). The oven temperature was programmed from 100 to $200{ }^{\circ} \mathrm{C}$ at $8{ }^{\circ} \mathrm{C} / \mathrm{min}$ and maintained at this temperature for $5 \mathrm{~min}$. The injection was carried out in the splitless mode and the injection port temperature was $200{ }^{\circ} \mathrm{C}$. For each experimental prototype, two replicate analyses were performed, including one smoking run (10 cigarettes) and the subsequent chemical analysis. 


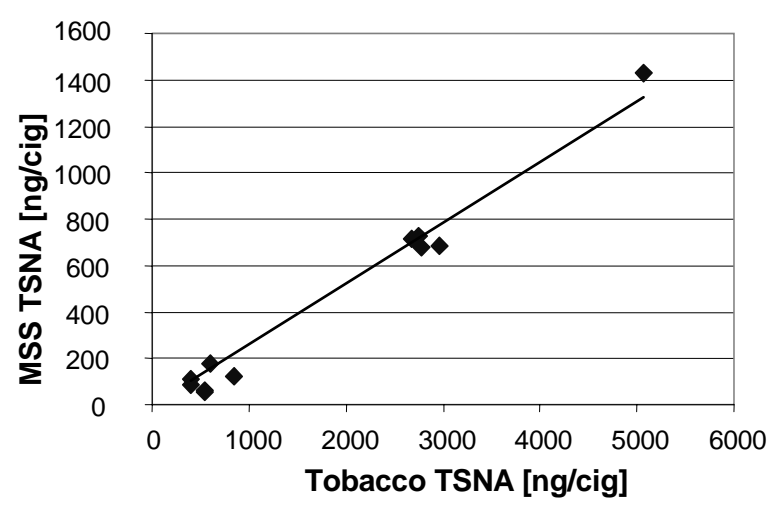

Figure 5. Dependence of the MSS TSNA on tobacco TSNA for the set of burley samples. Tobacco TSNA levels are expressed in $n g$ TSNA/g tobacco dry weight

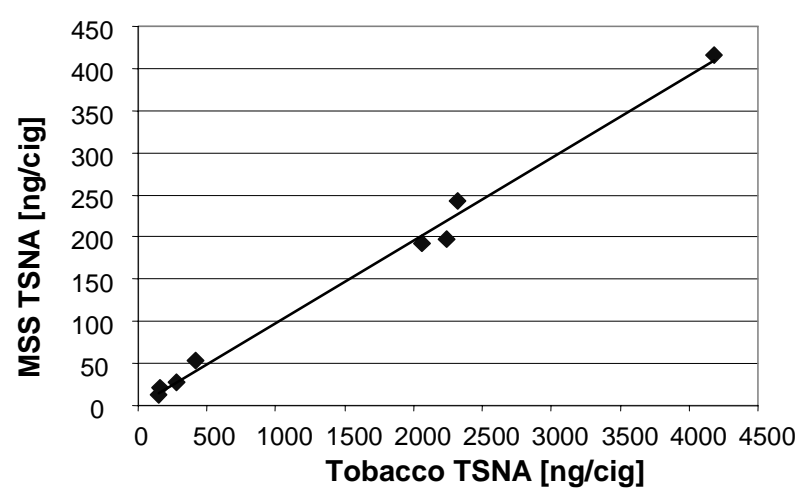

Figure 6. Dependence of the MSS TSNA on tobacco TSNA for the set of flue-cured samples. Tobacco TSNA levels are expressed in $\mathrm{ng}$ TSNA/g tobacco dry weight.

\section{RESULTS AND DISCUSSION}

\section{Determination of the mainstream-to-tobacco TSNA ratio for the different blend components}

The mainstream-to-tobacco TSNA ratios were calculated as the slope of the regression line mainstream- vs. tobaccoTSNA. Calculations were carried out separately for burley and flue-cured. As for Oriental tobacco, the ratio was calculated as MSS TSNA/tobacco TSNA for the single prototype made of $100 \%$ Oriental tobacco. The ratios obtained for each type of tobacco were used as transfer rates to predict the MSS TSNA delivery based on the TSNA levels of the blend components.

Mainstream-to-tobacco TSNA ratios for total TSNA: The calculation of the ratios for each tobacco type was based on the data from the single-component (see Appendix 1) as well as from selected two-component prototypes. The latter included the prototypes incorporating only one tobacco type (e.g. US and Malawi burley) and those prototypes in which one component had a largely predominant contribution to the total TSNA level (e.g., US burley blended with Greek Oriental). This approach was selected in order to base the calculation on the largest number of samples possible with the available data set.
Table 4. Mainstream-to-tobacco TSNA ratios for individual TSNA $^{\mathrm{a}}$

\begin{tabular}{l|c|c|c|c}
\hline \multirow{2}{*}{$\begin{array}{l}\text { Nitrosamine/ } \\
\text { tobacco type }\end{array}$} & \multicolumn{2}{|c|}{ Flue-cured } & \multicolumn{2}{c}{ Burley } \\
\cline { 2 - 5 } & Slope & $r^{2}$ & Slope & $r^{2}$ \\
\hline NNN & 0.10 & 0.996 & 0.23 & 0.987 \\
NAT & 0.09 & 0.997 & 0.27 & 0.967 \\
NAB & 0.18 & 0.841 & 1.73 & 0.841 \\
NNK & 0.10 & 0.993 & 0.37 & 0.974 \\
\hline
\end{tabular}

${ }^{a}$ The ratios were determined as the slope of the regression line mainstream-vs. tobacco-TSNA, with the intercept set to zero. In a first calculation run, the intercept was found not to be statistically different from zero for each nitrosamine in both tobacco types.

The equations of regression lines were calculated: For both burley and flue-cured tobaccos, the $y$-intercept was found not to be statistically different from zero. In a second run, the intercepts were forced to zero and the resulting slopes were taken as transfer rate. The observed values were 0.26 for burley and 0.10 for flue-cured tobaccos. For Oriental tobacco, the transfer rate was calculated as 0.10 . The coefficients of determination $\left(r^{2}\right)$ for the burley and the flue-cured samples were 0.977 and 0.993 respectively, indicating that the mainstream-to-tobacco TSNA ratios were quite homogenous across the different samples (see Figures 5 and 6). It is worth noting that the $r$ square values were only marginally reduced (burley: 0.969 , flue-cured: 0.984 ) if the samples isolated at the high end of the respective TSNA ranges were excluded from the calculation. Mainstream-to-tobacco TSNA ratios for individual TSNA: These ratios could provide indications regarding the prevalent mechanism leading to the presence of TSNA in MSS. It is expected that the different TSNA exhibit sufficiently similar volatility to present essentially the same mainstream-to-tobacco ratio if their presence in smoke occurs only from direct transfer from the tobacco. Significantly different ratios would instead suggest that chemical reactions taking place to various degrees during the tobacco combustion process might also influence the levels of TSNA in smoke. Pyrosynthetic formation and thermal degradation of TSNA are two relevant mechanisms in this context. With respect to the TSNA reduction effort, thermal degradation would primarily be regarded as a positive effect. Instead, pyrosynthetic formation could significantly reduce the benefits of the TSNA reduction in cut-filler and therefore the discussion below is focused on pyrosynthesis. As different transfer rates of total TSNA have been observed for burley and flue-cured tobaccos, the calculations for the individual TSNA could not be performed on prototypes mixing different tobacco types. These calculations were based on all single-type cigarettes, i.e., the six single grade prototypes and four two-component prototypes. As for total TSNA, the ratios were determined as the slope of the regression line mainstream vs. tobacco TSNA. The obtained values are shown in Table 4. As such, the data set appears too small to draw firm conclusions; however, useful qualitative observations could be made. For the prototypes made of flue-cured tobaccos, the calculated mainstream-to-tobacco TSNA ratios for NNN, 


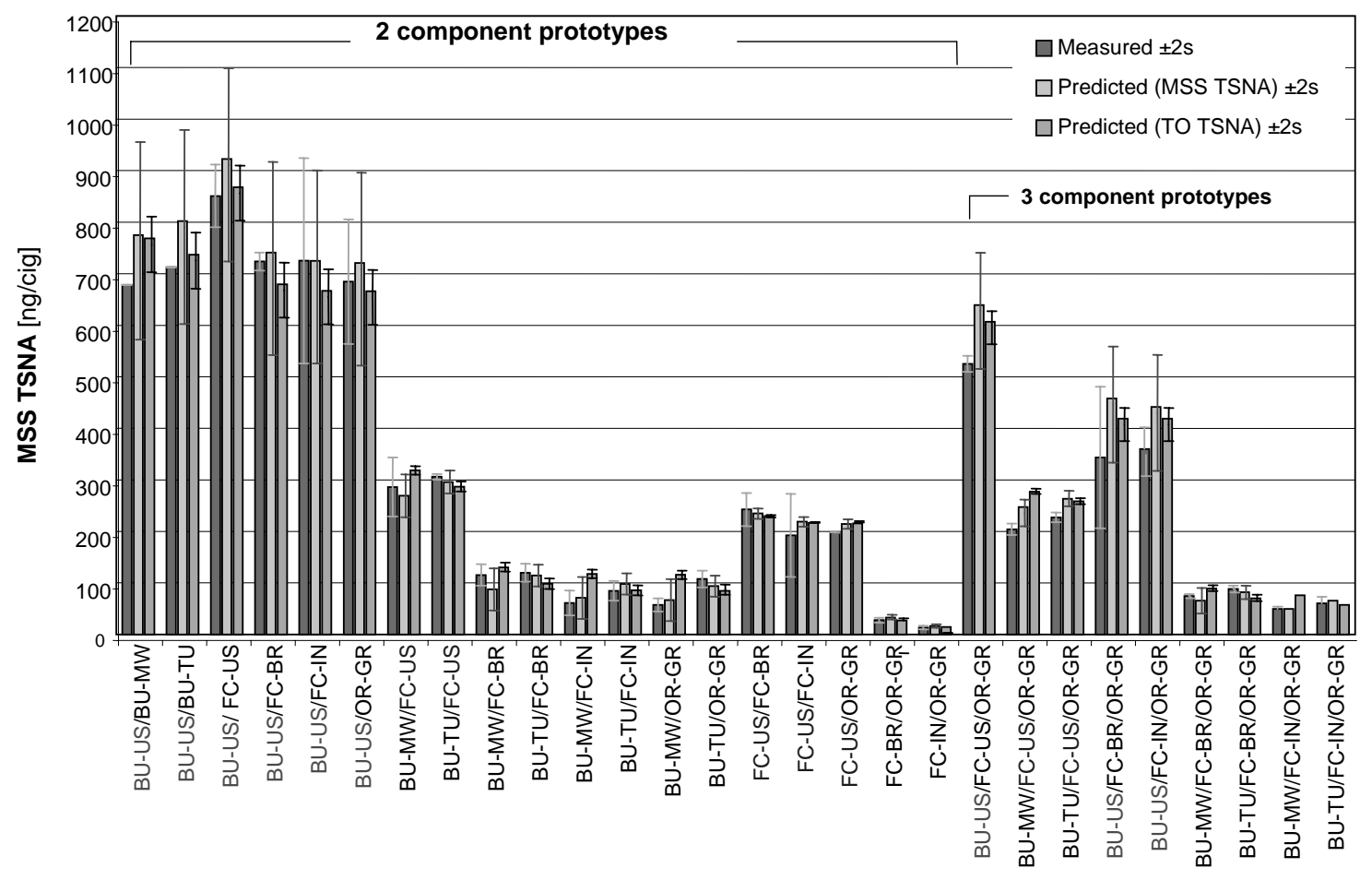

Figure 7. Comparison of measured and predicted TSNA levels for the different experimental prototypes. Error bars correspond to the \pm 2 s limits.

NAT and NNK were almost identical while the ratio for NAB was clearly higher.

With respect to the burley prototypes, the mainstream-totobacco TSNA ratios for NNN and NAT were comparable. The remaining two nitrosamines, NAB and NNK seemed to behave differently as they showed higher mainstream-totobacco TSNA ratios.

In line with the above expectations, the equivalence of the ratios for NNN, NAT and NNK in the flue-cured singlecomponent prototypes as well as for NNN and NAT in the burley single-component prototypes, was considered as an indication that the contribution of pyrosynthesis was very minor. The presence of these TSNA in MSS thus appeared to result essentially from the transfer of the pre-formed compounds.

A contribution of pyrosynthesis, although limited, could not be excluded for NAB in both burley and flue-cured samples, and for NNK in burley samples. Information supporting the possible pyrosynthetic formation of NAB during the combustion process was published by FISCHER et al. (11). Another possible reason for the higher proportion of NAB in MSS might be a minor artifactual formation of NAB on the Cambridge filter due to the relative ease of nitrosation of anabasine as reported by CALDWELL et al. (15).

Although the above subset of data was not sufficient to derive statistically supported conclusions, useful qualitative observations could be made, that in our opinion, support the fact that the combustion process did not affect in any statistically significant way, the proportion of the NNN and NNK. Indeed NNN appeared to be unaffected across the range of experimental cigarette prototypes. In those instances where NNK could have been affected, the absolute impact on the total TSNA level was insignificant, given the very low absolute amount in which NNK occurred.

\section{Prediction of the MSS TSNA levels of the blended prototypes}

Prediction based on the delivery of the single-component prototypes: In a first stage, the measured TSNA levels of the different prototypes were compared with the predicted values (see Appendix 2) calculated by combining the TSNA deliveries of the single-component prototypes according to their percentage in the blended prototypes. As illustrated in Figure 7, the predicted and the measured levels were in agreement. The average error in the prediction considering the whole set of samples was calculated as $+7 \%$. The observed discrepancy between the predicted and the measured values could be attributed to the very limited number of samples considered for the study and to the limited number of replicates of each analysis $(n=2)$.

It is important to note that the measured TSNA deliveries were generally lower than the predicted ones. This would not be the case if a pyrosynthetic process involving crossreactions between a high-nitrate component and the rest of the blend had occurred. On the other hand, a careful examination of the data for the prototypes containing Oriental tobacco led to the conclusion that there was no inhibitory effect of the Oriental tobacco on any nitrosation 
reaction possibly occurring during the combustion process. Therefore, the obtained data strongly suggested that the TSNA deliveries of the single blend components were additive and that no chemical reaction took place between the different blend components.

Prediction based on the levels of pre-formed TSNA levels: In a second stage, the TSNA levels measured in the MSS of the different experimental prototypes were compared (see Appendix 2) with the predicted values based on the preformed TSNA levels of the blend components and the calculated transfer rates, i.e., $26 \%$ for burley and $10 \%$ for flue-cured and Oriental. As shown in Figure 7, the predicted values based on the pre-formed TSNA levels were in agreement with the measured values. The average error in the prediction considering the whole set of samples was calculated as $+11 \%$. The tobacco TSNA levels provided therefore a fairly good basis to predict the amount of TSNA delivered to the MSS.

More generally, it appeared from this study that the preformed TSNA levels fully determined the amount of TSNA delivered to MSS of an all-lamina cigarette. This finding clearly supports the use of low-TSNA tobaccos (Figure 7). The obtained results also showed that the strongest effect was observed upon substituting the burley rather than the flue-cured tobacco component. The replacement of the standard flue-cured tobacco by a low-TSNA tobacco lowered the TSNA delivery of the standard two-component prototype made of flue-cured and burley tobacco from the USA by only $15 \%$ and that of the three-component blend by $35 \%$. The higher reduction achieved in the latter case was due to the higher proportion of flue-cured vs. burley tobacco (30\% vs. 20\%). These values have to be compared with the $60 \%$ reduction achieved for both the two- and the three-component blends when the burley rather than the flue-cured tobacco component was substituted.

\section{CONCLUSIONS}

As a consequence of recent technical changes during the flue-curing of tobacco, the reduction of pre-formed TSNA appears at present to be the most promising approach towards a reduction of TSNA in mainstream smoke. The results of the present study support this approach as they provide strong indications that the use of low TSNA strips leads to low TSNA levels in MSS of the blends. It also appeared that the major contributor to the TSNA in MSS was the burley component of the simplified burley-fluecured-Oriental model blend. The combination of two characteristics of the burley tobacco supported this observation, namely, the higher pre-formed TSNA levels and the higher transfer of TSNA into MSS for burley compared with flue-cured and Oriental tobaccos.

While the present experiment was not designed to provide a formal assessment of the respective contribution of transfer vs. pyrosynthesis to the levels of TSNA in MSS, it provided experimental data suggesting that direct transfer is the dominant factor explaining the presence of TSNA in MSS. The observed TSNA transfer rates appeared to be quite homogeneous within a given type of tobacco.

The absence of interactions between the blend components, the limited role of pyrosynthesis and the constant transfer rates for a given tobacco type allowed the prediction of MSS TSNA deliveries. The results of the present study very clearly showed that the MSS TSNA levels of the blended prototypes could be predicted based on the MSS or even on the tobacco TSNA levels of the blend components. The possibility of prediction based on the pre-formed TSNA levels was particularly interesting as the analysis of tobacco samples is much less labor intensive than that of TSNA in smoke.

Although the results obtained in this study were very promising, their scope was still limited by the fact that very simplified blends were considered and only a limited number of analyses was performed. The influence of other components of the cigarette blend such as expanded and reconstituted tobaccos as well as stems still needs to be assessed. In addition, if a tool for the prediction of MSS TSNA deliveries has to be developed in the future, the precision of the model needs to be increased by the analysis of more samples and of more replicates per sample.

\section{ABBREVIATIONS}

$\begin{array}{ll}\text { BU: } & \text { Burley tobacco } \\ \text { FC: } & \text { Flue-cured tobacco } \\ \text { GC: } & \text { Gas chromatography } \\ \text { MSS: } & \text { Mainstream smoke } \\ \text { NAB: } & N \text {-nitrosoanabasine } \\ \text { NAT: } & N \text {-nitrosoanatabine } \\ \text { NDHEXA: } & N \text {-nitrosodihexylamine } \\ \text { NNN: } & N \text {-nitrosonornicotine } \\ \text { NNK: } & \text { 4-(N-methyl- } N \text {-nitrosoamino)-1-(3-pyridyl)- } \\ & \text { 1-butanone } \\ \text { OR: } & \text { Oriental tobacco } \\ \text { RTD: } & \text { Resistance to draw } \\ \text { TEA: } & \text { Thermal energy analyzer } \\ \text { TSNA: } & \text { Tobacco specific nitrosamines }\end{array}$

Acknowledgements: The authors are grateful to Mrs. V. Mousson for performing the analyses. Messrs. A. Tuzzolino and B. Barbou, together with their respective staffs are acknowledged for the preparation of the experimental cigarette prototypes.

\section{REFERENCES}

1. Williams, J.R.: Method of treating tobacco to reduce nitrosamine content, and products produced thereby; International Patent No. WO 98/05226 (February 1998).

2. Peele, D.M., M.G. Riddick, and M.E. Edwards: Formation of tobacco specific nitrosamines in flue-cured tobacco; CORESTA, Meeting of the smoke and technology study groups, 5-9th September 1999, Innsbruck, Austria.

3. Baker, R.R.: Smoke chemistry; in: Tobacco, Production, Chemistry and Technology, edited by D.L. Davis and M.T. Nielsen, Blackwell Science, London, 1999, pp. 425-427.

4. Spiegelhalder, B. and H. Bartsch: Tobacco-specific nitrosamines; H. Eur. J. Cancer Prev. 5 (1996) 33-38. 
5. Wahlberg, I., A. Wiernik, A. Christakopoulos, and L. Johansson: Tobacco-specific nitrosamines. A multidisciplinary research area; Agro-Food-Industry HiTech. 6 (1999) 23-28.

6. Burton, H.R., N.K. Dye, and L.P. Bush: Relationship between tobacco-specific nitrosamines and nitrite from different air-cured tobacco varieties; J. Agric. Food Chem. 42 (1994) 2007-2011.

7. Chamberlain, W.J. and O.T. Chortyk: Effects of curing and fertilization on nitrosamine formation in bright and burley tobacco; Beitr. Tabakforsch. Int. 15 (1992) 87-92.

8. Burton, H.R., M. Cui, and L. Bush: Environmental parameters affecting TSNA accumulation during aircuring tobacco; presentation given at the 1998 TSRC Meeting in Atlanta.

9. Hoffmann, D., M. Dong, and S.S. Hecht: Origin in tobacco smoke of $N$-nitrosonornicotine, a tobaccospecific carcinogen; J. Natl. Cancer Inst. 58 (1977) 1841-1844.

10. Adams, J.D., S.J. Lee, N. Vinchkoski, A. Castonguay, and D. Hoffmann: On the formation of the tobaccospecific carcinogen 4-(methylnitrosamino)-1-(3-pyridyl)-1-butanone during smoking; Cancer Lett. 17 (1983) 336-346.

11. Fischer, S., B. Spiegelhalder, J. Eisenbarth, and R. Preussmann: Investigations on the origin of tobaccospecific nitrosamines in mainstream smoke of cigarettes; Carcinogenesis 11 (1990) 723-730.
12. Hoffmann, D., J.D. Adams, K.D. Brunnemann, and S.S. Hecht: Assessment of tobacco-specific $N$-nitrosamines in tobacco products; Cancer Res. 39 (1979) 2505-2509.

13. ISO 3402: Tobacco and tobacco products - Atmosphere for conditioning and testing; International Organization for Standardization, Geneva, Switzerland, 1999.

14. ISO 3308: Routine analytical cigarette-smoking machine - Definitions and standard conditions; International Organization for Standardization, Geneva, Switzerland, 2000.

15. Caldwell, W.S. and J.M. Conner: Artifact formation during smoke trapping - An improved method for determination of $N$-nitrosamines in cigarette smoke; J. Assoc. Off. Anal. Chem. 73 (1990) 783-789.

\section{Address for correspondence:}

Jean-Marc Renaud

Philip Morris International

Research and Development

clo Philip Morris Product SA

Quai Jeanrenaud 56

CH-2003 Neuchâtel

Switzerland

e-mail: Jean-Marc.Renaud@pmintl.com

APPENDIX 1. Analysis of TSNA in tobacco and in MSS of the single-component prototypes. Tobacco TSNA levels are expressed in ng TSNA/g tobacco dry weight.

\begin{tabular}{|c|c|c|c|c|c|c|c|}
\hline $\begin{array}{l}\text { Prototype } \\
\text { Blend type }\end{array}$ & $\begin{array}{c}\text { 001P } \\
\text { BU-US }\end{array}$ & $\begin{array}{c}\text { 002P } \\
\text { BU-MW }\end{array}$ & $\begin{array}{c}\text { 003P } \\
\text { BU-TU }\end{array}$ & $\begin{array}{l}\text { 004P } \\
\text { FC-US }\end{array}$ & $\begin{array}{l}\text { 005P } \\
\text { FC-BR }\end{array}$ & $\begin{array}{l}\text { 006P } \\
\text { FC-IN }\end{array}$ & $\begin{array}{c}\text { 007P } \\
\text { OR-GR }\end{array}$ \\
\hline \multicolumn{8}{|c|}{ Tobacco } \\
\hline NNN (ng/g) & 4058 & 688 & 500 & 1208 & 145 & 23 & 52 \\
\hline NAT (ng/g) & 3025 & 527 & 413 & 1689 & 212 & 67 & 31 \\
\hline NAB (ng/g) & 94 & 38 & 26 & 101 & 11 & 11 & 12 \\
\hline NNK (ng/g) & 333 & 207 & 100 & 2145 & 142 & 94 & 46 \\
\hline Total TSNA (ng/g) & 7510 & 1460 & 1039 & 5144 & 510 & 195 & 141 \\
\hline \multicolumn{8}{|c|}{ MSS } \\
\hline No. of puffs (TSNA lab) & 7.98 & 6.19 & 6.07 & 11.00 & 10.95 & 10.24 & 14.24 \\
\hline NNN (ng/cig) & 657 & 41 & 70 & 99 & 12 & 4 & 4 \\
\hline NAT (ng/cig) & 596 & 33 & 69 & 127 & 19 & 6 & 4 \\
\hline NAB (ng/cig) & 90 & 7 & 10 & 16 & 5 & 2 & 1 \\
\hline NNK (ng/cig) & 86 & 41 & 27 & 173 & 18 & 9 & 4 \\
\hline Total TSNA (ng/cig) & 1429 & 122 & 175 & 417 & 53 & 21 & 12 \\
\hline
\end{tabular}




\begin{tabular}{|c|c|c|c|}
\hline 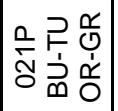 & 응 চ & 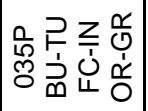 & 8 م \\
\hline 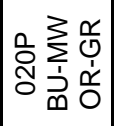 & กิ & 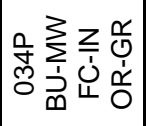 & g g \\
\hline 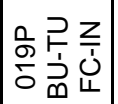 & 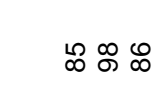 & 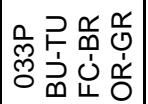 & $\infty \propto$ \\
\hline $\mid \begin{array}{lll}0 & 3 & z \\
\infty & \sum_{j} & z \\
0 & j & j \\
0 & 0 & 4\end{array}$ & 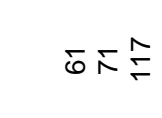 & 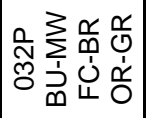 & స \\
\hline 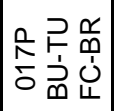 & 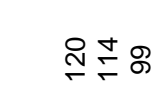 & 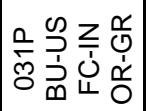 & 兽 导尔 \\
\hline 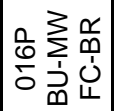 & 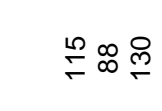 & 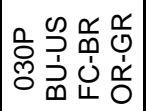 & 胥占尔 \\
\hline 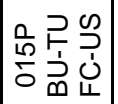 & 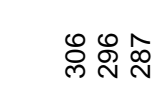 & 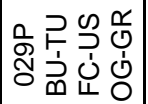 & స్ \\
\hline 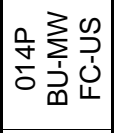 & 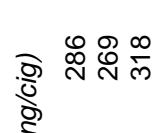 & 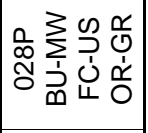 & क্তু \\
\hline 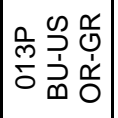 & 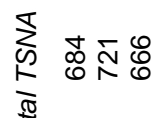 & 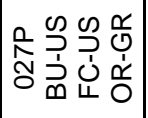 & 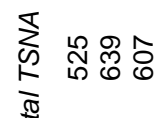 \\
\hline 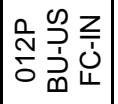 & 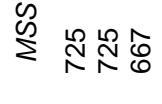 & 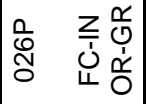 & $\stackrel{\mathscr{D}}{\sum} \cong \sim$ \\
\hline 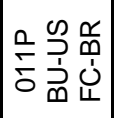 & 衣过 & 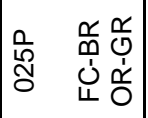 & $\stackrel{\sim}{\sim} \mathbb{m} \curvearrowright$ \\
\hline 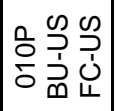 & Г⿸尸 & 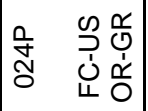 & $\stackrel{\infty}{\stackrel{\sim}{\sim}} \stackrel{+}{\sim} \stackrel{\infty}{\sim}$ \\
\hline | & 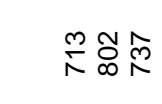 & 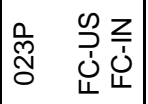 & 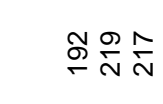 \\
\hline 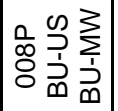 & 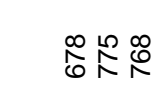 & 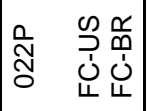 & 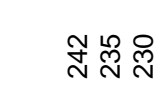 \\
\hline 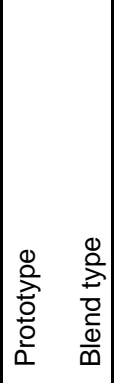 & 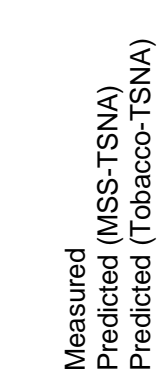 & 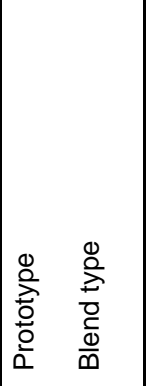 & 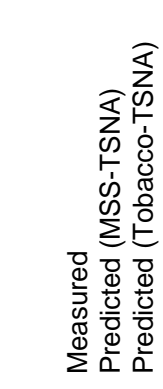 \\
\hline
\end{tabular}

